\title{
Comparative proteome analysis reveals VPS28 regulates milk fat synthesis through ubiquitylation in bovine mammary epithelial cells
}

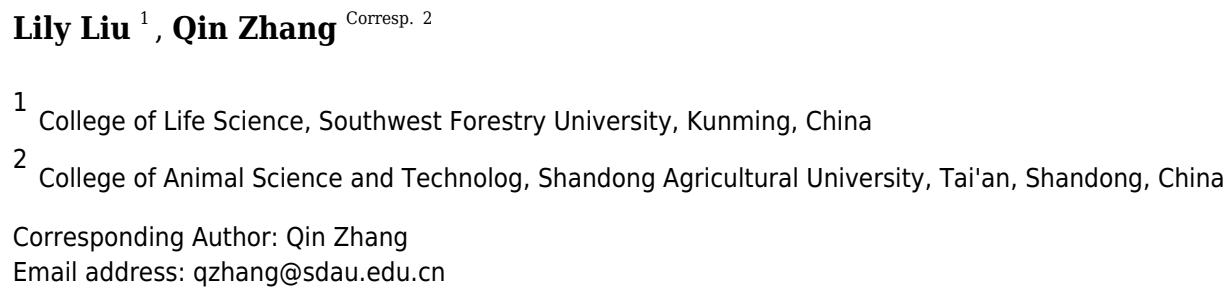

In our previous study, we found VPS28 (vacuolar protein sorting 28 homolog) could alter ubiquitylation level to regulate milk fat synthesis in BMECs (bovine primary mammary epithelial cells). While the information on the regulation of VPS28 on proteome of milk fat synthesis is less, we explored its effect on milk fat synthesis using iTRAQ (isobaric tags for relative and absolute quantitation) assay after knocking down VPS28 in BMECs. We found 2,773 proteins in three biological replicates with less than in $1.2 \%$ false discovery rate were identified and quantified. Among them, a subset of 203 proteins were screened as significantly down- (111) and up- (92) regulated inVPS28 knockdown BMECs compared with the control groups. According to Gene Ontology analysis, the differentially expressed proteins were enriched in the "proteasome", "ubiquitylation", "metabolism of fatty acids", "phosphorylation", and "ribosome". Meanwhile, some changes occurred in the morphology of BMECs and an accumulation of TG (triglyceride) and dysfunction of proteasome were identified, and a series of genes associated with milk fat synthesis, ubiquitylation and proteasome pathways were analyzed by RT-QPCR (quantitative real-time PCR). The results of this study suggested VPS28 regulated milk fat synthesis was mediated by ubiquitylation, it could be an important new area of study for milk fat synthesis and other milk fat content traits in bovine. 
1 Comparative proteome analysis reveals VPS28 regulates milk fat 2 synthesis through ubiquitylation in bovine mammary epithelial cells

3 Lily Liu ${ }^{1}$, Qin Zhang ${ }^{2 *}$

$4{ }^{1}$ College of Life Science, Southwest Forestry University, Kunming, Yunnan 650224, China;

$5 \quad{ }^{2}$ College of Animal Science and Technology, Shandong Agricultural University, Tai'an,

6 Shandong 271000, China

7

*Corresponding to

Qin Zhang, PhD, Professor

2 Daizong Road, Tai'an, China

Email: qzhang@sdau.edu.cn 


\section{Abstract}

In our previous study, we found VPS28 (vacuolar protein sorting 28 homolog) could alter ubiquitylation level to regulate milk fat synthesis in BMECs (bovine primary mammary epithelial cells). While the information on the regulation of VPS28 on proteome of milk fat synthesis is less, we explored its effect on milk fat synthesis using iTRAQ (isobaric tags for relative and absolute quantitation) assay after knocking down VPS28 in BMECs. At a false discovery rate of $1.2 \%$, We found 2,773 proteins in three biological replicates. Among them, a subset of 203 proteins were screened as significantly down- (111) and up- (92) regulated inVPS28 knockdown BMECs compared with the control groups. According to Gene Ontology analysis, the differentially expressed proteins were enriched in the "proteasome", "ubiquitylation", "metabolism of fatty acids", "phosphorylation", and "ribosome". Meanwhile, some changes occurred in the morphology of BMECs and an accumulation of TG (triglyceride) and dysfunction of proteasome were identified, and a series of genes associated with milk fat synthesis, ubiquitylation and proteasome pathways were analyzed by qRT-PCR (quantitative real-time PCR). The results of this study suggested VPS28 regulated milk fat synthesis was mediated by ubiquitylation, it could be an important new area of study for milk fat synthesis and other milk fat content traits in bovine.

Keywords: VPS28; milk fat synthesis; iTRAQ; proteome; ubiquitylation 


\section{Introduction}

VPS28 is a member of the class E VPS proteins, and also is a major component of ESCRT I

43 (endosomal sorting complexes required for transport I). ESCRT-0, ESCRT-I, ESCRT-II,

44 ESCRT-III and some auxiliary components constitute ESCRTs, play crucial roles in

45 concentration and sorting of ubiquitinated proteins of the MVB (multivesicular body) for

46 incorporation into ILV (intralumenal vesicles) (1-3). The importance of ESCRTs was

47 demonstrated by Raymond et al., who showed that disruption of ESCRTs resulted in an

48 accumulation of membrane proteins and no longer degraded in the vacule (4). Recent studies

49 showed that ESCRTs play a critical role in degradation of ubiquitinated proteins through

50 lysosome and proteasom $(5,6)$. Particularly, VPS28 is localized to ubiquitin-rich endosomes

51 during ligand-induced receptors internalization and contributes directly to receptor trafficking (7).

52 In previous studies, we found a SNP in the 5' UTR region of VPS28 showed a very strong

53 association with milk fat percentage and its expression level significantly affected milk fat

54 synthesis in Chinese Holstein (8-11). Based on the structural feature and function of ESCRTs,

55 we believed that VPS28 could regulate milk fat synthesis through engaging ESCRTs complexes

56 to affect the ubiquitin-mediated degradation of proteins, which has been proved in our previous

57 study $(8,12)$. However, the molecular mechanisms of VPS28 response to milk fat synthesis still

58 remain unclear. Thus, in present study, to better understand the mechanisms, we used iTRAQ

59 technology that allows quantitative comparisons of protein abundance to much greater insight

60 into the regulation of VPS28 on milk fat synthesis in Chinese Holstein. After performing RNAi 
61

62

experiment in BMECs, we compared the knockdown BMECs groups with the control groups to identify differentially expressed proteins by iTRAQ. Changes in the expression patterns of the proteins could provide a basis for clarifying the molecular mechanisms for VPS28 regulating milk fat synthesis in Chinese Holstein, which may be a forward step for milk fat synthesis regulation, In addition, this study can provide a reference for elucidating the molecular mechanisms of milk fat traits.

\section{Materials and Methods}

\section{Animals}

The procedures of collecting BMECs from the mammary tissues of Chinese Holstein cows according to the Animal Welfare Committee of Shandong Agricultural University (Permit Number is SDAUA-2018-022).

\section{Cell Culture}

Cell culture experiments were performed using primary BMECs. Chemicals were purchased from Life Technologies (Carlsbad, CA, USA) unless noted otherwise. Primary BMECs were kept in our laboratory. BMECs were plated in serum-containing medium DMEM-F12 supplemented with $10 \mathrm{kU} / \mathrm{mL}$ penicillin, $10 \mathrm{mg} / \mathrm{mL}$ streptomycin, $10 \%$ fetal bovine serum (FBS) and $1 \%$ ITS $-\mathrm{G}(1 \mathrm{mg} / \mathrm{mL}$ Insulin, $0.55 \mathrm{mg} / \mathrm{mL}$ Transferrin, $0.67 \mathrm{mg} / \mathrm{L}$ Selenium Solution). All cells were cultured on plastic cell culture plates at $37^{\circ} \mathrm{C}$ in a humidified atmosphere containing $5 \% \mathrm{CO}_{2}$.

Knockdown of VPS28 via RNAi in BMECs 
Stealth RNAi $^{\mathrm{TM}}$ siRNAs targeting the bovine VPS28 gene open reading frame were

82

83

84

85 designed and synthesized by GenePharma Corporation (Shanghai, China). One day prior to transfection, BMECs were seeded without antibiotics. When cells reached $80 \%$ confluence, VPS28-siRNAs (GUCCAGGGCUCAGAAAUCATT and GACGUGGUCUCGCUCUUUATT) as tandem constructs, were transfected in to BMECs using X-treme GENE siRNA Transfection Reagent (Roche, Penzberg, Germany) at a 1:10 molar ratio. Cells were harvested at 72 hours after transfection for mRNA analysis via real-time quantitative PCR (RT-qPCR).

\section{Sample Preparation}

Six BMECs samples from two groups (control and VPS28 knockdown) were incubated in lysis buffer (7 M urea, $2 \mathrm{M}$ thiourea and $0.1 \%$ CHAPS) for $30 \mathrm{~min}$ on ice and sonicated ( $80 \mathrm{~W}$, ultrasonic $0.2 \mathrm{~s}$, intermittent $2 \mathrm{~s}$, a total $60 \mathrm{~s}$ ) on ice. Cells debris was pelleted by centrifugation at $15,000 \mathrm{~g}$ for $20 \mathrm{~min}$ at $4{ }^{\circ} \mathrm{C}$. The supernatants were collected and stored at $-80{ }^{\circ} \mathrm{C}$. The protein concentration was determined using Bradford assay (Sigma-Aldrich, USA).

\section{Protein digestion and iTRAQ labeling}

Protein digestion was performed using the filter aided sample preparation (FASP) method. Each protein extract $(200 \mu \mathrm{g})$ was mixed with $4 \mu \mathrm{L}$ reducing reagent (AB Sciex, USA) for 1 hour at $60{ }^{\circ} \mathrm{C}$ and $2 \mu \mathrm{L}$ cysteine-blocking reagent for $10 \mathrm{~min}$ at room temperature, the alkylated protein solution was added to $10 \mathrm{~K}$ ultrafiltration tube and discarded the filtrate after centrifuging at $12,000 \mathrm{~g}$ for $20 \mathrm{~min}$. Then $100 \mu \mathrm{L}$ dissolution buffers were added to the filtered unit and the solution was centrifuged again at 12,000 $\mathrm{g}$ for $20 \mathrm{~min}$ and repeated 3 times. After incubating overnight, the units were transferred to new collection tubes, and then adding $4 \mu \mathrm{g}$ trypsin 
102 (protein to enzyme ratio 50: $1 \mathrm{w} / \mathrm{w}$ ) and mixed them at $37{ }^{\circ} \mathrm{C}$ for overnight. The units were 103 centrifuged at $12,000 \mathrm{~g}$ for $20 \mathrm{~min}$ discarded the filtrate, then added $50 \mu \mathrm{L}$ dissolution buffer 5 104 and centrifuged $12,000 \mathrm{~g}$ for $20 \mathrm{~min}$ incubated at room temperature. Finally, the extracted

105

106

107

108

109

110

111 peptides were collected from bottom.

The iTRAQ labeling was performed according to the manufacturer's protocol (AB, Sciex). After trypsin digestion, the peptides were transferred to vials containing individual iTRAQ regents by incubation at room temperature for 2 hours, which was thawed and reconstituted in $150 \mu \mathrm{L}$ isopropanol per one unit. The three knock-down VPS28 groups were labeled with iTRAQ 115, 116 and 117; the three WT groups were labeled with iTRAQ 118, 119 and 121, respectively.

\section{Peptide fractionation with SCX (strong cation exchange) chromatography}

The iTRAQ labeled peptides were fractionated by SCX using RIGOL L-3000 HPLC system (RIGOL, Beijing, China). The dried peptide was dissolved with $100 \mu \mathrm{L}$ buffer $\mathrm{A}\left(98 \% \mathrm{ddH}_{2} \mathrm{O}\right.$, $2 \%$ acetonitrile) and the solution was centrifuged at $14,000 \mathrm{~g}$ for $20 \mathrm{~min}$, the supernatants were collected. The peptides were eluted at a flow rate of $0.7 \mathrm{ml} / \mathrm{min}$ with a buffer B $(98 \%$ acetonitrile, $2 \% \mathrm{H}_{2} \mathrm{O}$ ) gradient of $5 \%$ at $0-5 \mathrm{~min}, 8 \%$ at $5-35 \mathrm{~min}, 18 \%$ at $35-62 \mathrm{~min}, 32 \%$ at $62-64 \mathrm{~min}, 95 \%$ at $64-68 \mathrm{~min}, 5 \%$ at $72 \mathrm{~min}$. The elution was monitored by absorbance at $214 \mathrm{~nm}$.

\section{Quantitative analysis of proteins by iTRAQ LC-MS/MS}

Each collected component of the processed SCX fractions was redissolved with $20 \mu \mathrm{L} 2 \%$ methanol and $0.1 \%$ formic acid, and the solution was centrifuged at $12,000 \mathrm{~g}$ for $10 \mathrm{~min}$, the supernatants were collected. $10 \mu \mathrm{L}$ solution was trapped on a precolumn $(100 \mu \mathrm{m} \times 2 \mathrm{~cm})$ and 
123 then eluted on an analytical column $(75 \mu \mathrm{m} \times 12 \mathrm{~cm})$ for separation. The precolumn was packed

124 with Acclaim PepMap-C18 $5 \mu \mathrm{m}$ and analytical column was packed with EASY-Spray-C18 3

$125 \mu \mathrm{m}$. The peptides were separated over $90 \mathrm{~min}$ and eluted at a flow rate of $350 \mathrm{nl} / \mathrm{min}$. The MS

126 analysis was performed using an Applied Biosystems Q-Exactive mass spectrometer.

127 The BMECs iTRAQ identification and quantification analysis were obtained using 128 Proteome Discoverer1.3 (Thermo, USA). Proteome Discoverer1.3 was set up to search the NCBI 129 Bos taurus major database assuming the digestion enzyme trypsin. The differential expressed proteins were accepted if they have been identified with greater than $95 \%$ confidence in all

iTRAQ preparations, and have $\geqslant 1.2$ or $\leqslant 0.83$ fold changes (iTRAQ ratios (VPS28 knockdown)to annotate the proteins under the biological progress (BP), molecular function (MF) and cellular components (CC) GO categories (DAVID, https://david.ncifcrf.gov/) in the BMECs.

\section{Microscopy analysis}

The control and VPS28 knockdown BMECs were collected and fixed with 2.5\%

The fixed BMECs were cut into 1-um-thick sections and stained with uranyl acetate and lead

Japan).

\section{Measurement of cellular TG content and proteasome activities}


The control and VPS28 knockdown BMECs were collected and broken by ultrasonication.

145 The total lipids were extracted using the TG assay Kit (Nanjing Jiancheng Bioengineering

146 Institute, China) and monitored with Infinite M200 Reader (Tecan, Switzerland).according to the

147 manufacturer's instructions.

148 The proteasome activities (Chymotrypsin-Like, Caspase-Like and Trypsin-Like) were

149 measured using the Proteasome-Glo ${ }^{\mathrm{TM}}$ Cell-Based Assays (Promega, Mannheim, Germany)

150 according to the manufacturer's instructions, and the fluorescence intensity was monitored with

151 Infinite M200 Reader (Tecan, Switzerland).

152

153

154

155

156

157

158

159

160

161

162

VPS28 knockdown alters expression of multiple proteins in BMEC

\section{Real-time quantitative PCR analysis} the $2^{-\Delta \Delta \mathrm{Ct}}$ method

\section{Statistical Analysis}

\section{Results}

The primers of selected genes for RT-qPCR were designed with Primer 5.0 and synthesized by The BGI (Beijing Genomics Institute) Co., Ltd. The GAPDH (glyceraldehyde-3-phosphate dehydrogenase) gene was used as the control. The primer sequences are listed in Table 1. RNA extraction, cDNA synthesis and RT-qPCR were performed according to the manufacturer's instructions, and were repeated three times. The relative expression of genes was computed using

R-package ( $\mathrm{R}$ v3.02) was conducted to evaluated changes between VPS28 knockdown BMECs groups and the control groups. And differences were declared significant at $P \leqslant 0.05$. 
shown in Fig. 1A), and then, to obtain a whole picture of the proteomic changes in VPS28

knockdown BMEC, we conducted iTRAQ experiment in combination with LC-ESI-MS/MS

analysis to investigate differentially expressed proteins in VPS28 knockdown BMECs groups

(labeled iTRAQ-115, 116 and 117) and the control groups (labeled iTRAQ-118, 119 and 121).

At a false discovery rate of $1.2 \%$, a total of 2,773 proteins were identified from 14,031 peptides.

The peptides of all proteins are provided in Supporting Information Table S1.

To further understand the differentially expressed proteins after knocking down VPS28 in

BMECs and basing on standard of the differentially expressed proteins, a total of 203 distinct

proteins were identified by iTRAQ analysis in VPS28 knockdown BMECs (Detailed gene information and fold-change following VPS28 knockdown were provided in Table 2). 92

proteins were significantly up-regulated $(\geqslant 1.2$-fold) while 111 proteins were significantly down-regulated $(\leqslant 0.83$-fold) when compared with the control BMECs.

The DEPs were categorized into 53 clusters $(P<0.05$, as shown in Table 3$)$ according to their biological processes (BPs), cellular components (CCs) and molecular functions (MFs). The top $6 \mathrm{GO}$ terms for BPs were enriched in cytoplasmic translation (GO: 0002181), translation

(GO: 0006412), cholesterol homeostasis (GO: 0042632), cholesterol efflux (GO: 0033344),

positive regulation of cholesterol esterification (GO: 0010873) and high-density lipoprotein

particle assembly (GO:0034380). These biological processes were involved in the lipid subunit (GO: 0022625), extracellular exosome (GO: 0070062), focal adhesion (GO: 005925), 
185

186

187

188

189

190

191

192

193

194

195

196

197

198

199

200

201

202

203

204

205

membrane (GO: 0016020) and very-low-density lipoprotein particle (GO: 0034361). These

cellular components were response to the ubiquitin system. The top $5 \mathrm{GO}$ terms for MFs were

mainly enriched in structural constituent of ribosome (GO: 0003735), RNA binding (GO:

0003723), cholesterol transporter activity (GO: 0017127), phosphatidylcholine-sterol O-

acyltransferase activator activity (GO: 0019843). These results showed that the DEPs following

VPS28 knockdown were mainly involved in the functions of transport and metabolism of lipid, lipoprotein and lipoprotein receptor binding, and ribosome translation.

\section{Effect of VPS28 knockdown on morphology of BMECs}

Electron micrographs could observe the morphological changes in BMECs. Compared with the control BMECs groups, the VPS28 knockdown groups showed containing more and strikingly large lipid droplets and many luminal spaces were completely filled with aggregated lipid (as shown in Fig. 1 B and C). And in parallel, the content of TG was increased by 3.3-fold above the control BMECs groups (Fig.1D).

The GO analysis demonstrated DEPs enriched in ubiquitylation singaling, and ubiquitylation mediates the degradation of membrane proteins and intracellular proteins, which plays an crucial role in receptor-mediated signaling pathways and quality control of intracellular proteins. And then we examined the proteasome activity (chymotreypsin-like activity, caspaselike activity, trypsin-like activity) after knocking down VPS28 (as shown in Fig. 2). The results showed that VPS28 knockdown could significantly decrease the three activites of proteasome, the relative activities of chymotreypsin-like, caspase-like and trypsin-like are $0.60,0.64,0.74$, respectively. And we also found the level of ubiquitinated proteins was increased by VPS28 
206 knockdown (the data has published) (12). These results indicated that VPS28 could regulate

207 ubiquitylation-proteasome system.

208 Validation of gene expression by RT-qPCR

209 To investigate whether the alteration of proteins expression level were the result of

210 transcriptional regulation, we detected mRNA levels of five selected proteins and five genes that

211 were related to metabolism of fatty acids, ubiquitylation and proteasome pathways. The RT-

212 qPCR results showed high qualitative and quantitative concordance (correlation coefficient

213 >0.95). As shown in Fig.3, CD36 (cluster of differentiation 36) in fatty acids taken up process,

$214 F A S N$ (fatty acid synthase), SCD (stearoyl-CoA desaturas) and DGAT1 (diacylglycerol

215 acyltransferase 1) in fatty acids synthesis pathway, $A D F P$ (adipose differentiation-related protein)

216 in lipid droplet secretion process, were all up-regulated by VPS28 knockdown. $A C A C A$ (acetyl-

217 CoA) in de novo fatty acids synthesis pathway was down-regulated in VPS28 knockdown

BMECs. PSMG1 (proteasome assembly chaperone 1) in proteasome system, RPS29 (ribosomal

protein S29) in ribosome translation pathway, $U B E 2 L$ (ubiquitin-conjugating enzyme E2L),

ISG15 (interferon-stimulatory gene ISG15) in ubiquitylation pathway, were all up-regulated by

VPS28 knockdown. The results showed that the mRNA expression levels of genes were

generally corresponded with the changes in the morphology of BMECs and proteins expression

detected by the iTRAQ approach.

\section{Discussion}


relationships exist which directly or indirectly could affect protein activity and regulate milk fat

227 synthesis, such as ubiquitylation and protein-protein interaction. Ubiquitylation is an important

228 post-translational modification and it can mediate the intercellular proteins degradation which

229 plays a crucial role in receptor-mediated signaling pathways. VPS28 as a subunit of ESCRTs is

230 crucial for ubiquitin-mediated degradation of proteins, and we found VPS28 could alter the

ubiquitylation level to regulate milk fat synthesis in previous studies $(8,12)$. However, much less is understood regarding the molecular mechanisms of VPS28 regulating milk fat synthesis

through ubiquitylation. In this study, iTRAQ technology were performed to accurately identify

the peptides and precisely quantify the iTRAQ labels. Subsequently, cluster and pathways

analysis were devoted to obtain consistent results to further elucidate the regulation pathways of

VPS28 on the milk fat synthesis.

The ubiquitin system is a protein degradation pathway, dedicates to the ubiquitylation of cellular targets and the subsequent control of numerous cellular functions and plays an important role in metabolism regulation(13). The deregulation of components of this elaborate network

leads to an accumulation of membrane proteins and no longer degraded in the vacule. Numerous studies indicated that, as one subunit of ESCRTs, VPS28 played a crucial role in ubiquitinmediated degradation of membrane proteins $(5,6)$ and cytoplasmic proteins (14). In this study, BMECs sections showed that the form of fat droplets was affected after knocking down VPS28, and we found an accumulation of ubiquitinated proteins and a dysfunction of proteasome activity in VPS28 knockdown BMECs groups. The proteomic analysis indentified many differentially 
247 membrane (GO: 0016020). These GO categories were associated with the ubiquitylation system.

248 These indicated that VPS28 knockdown played a crucial role in ubiquitylation.

249 In BMECs, fatty acids taken up and de novo fatty acids synthesis are involved in milk fat

250 synthesis. In our previous study, by knocking down VPS28 in BMECs, we found ubiquitinated

251 CD36 level was increased significantly which is the main protein involved in long-chain fatty

252 acids uptake, and the mRNA expression of other milk fat-related genes were also up-regulated.

253 These results indicated the process of long-chain fatty acids taken up was promoted by VPS28

254 knockdown in BMECs. In parallel, the expression of ADFP was found increased in VPS28

255 knockdown BEMCs. ADFP as a specific marker for lipid droplet, its expression level is in

256 keeping with with abundance of lipid droplets in cell (15). The proteomic analysis also

257 indentified many differentially expressed proteins enriched in lipid metabolism. These data

258 confirmed VPS28 knockdown could facilitate milk fat synthesis in BMECs.

259 The DEPs analysis indicates that VPS28 could regulate milk fat synthesis in two approaches,

260 the one is VPS28 directly regulates milk fat synthesis through ubiquitylation and the other one is

261 VPS28 mediates ubiquitin-proteasome system to regulate milk fat synthesis. To further

262 understand these, we used the key interact proteins and genes to generate the pathway networks,

263 following is the description of the model presented in Fig. 4:

VPS28 knockdown leads an accumulation of ubiquitinated membrane proteins to

promote fatty acids taken up to synthesize TG: In this regulation, CD36 appears to be the 
268 fatty acid and ubiquitinated CD36 facilitates long-chain fatty acids uptake (16-18). Following

269 VPS28 knockdown, the accumulation of ubiquitinated CD36 could import more long-chain fatty

270 acids into BMECs, and the imported long-chain fatty acids are combined and transported to

271 endoplasmic reticulum by FABP (fatty acid binding proteins). Subsequently, SCD and DGAT1

272 are induced to utilize fatty acids to synthesize TG. Therefore, VPS28 knockdown could promote

273 long chain fatty acids taken up to synthesize TG.

VPS28 knockdown leads an accumulation of ubiquitinated cytoplasmic proteins to

promote de novo biogenesis, activation and channelling of fatty acids to synthesize TG. In

this regulation, proteasome plays the most important role. Following VPS28 knockdown,

proteasome activity and the expression of ISG15 (interferon-stimulatory gene ISG15) were

decreased. ISG15 is an ubiquitin-like protein that mediates the conjugation of different proteins

through its ISGylation enzymes UBE2L6 (ubiquitin conjugating enzyme E2 L6) (19), and we

also found UBE2L6 was down regulated. Previous studies have suggested that down-regulation

of ISG15 and UBE2L6 can counteract degradation of triglyceride lipase (20-22), and ISG15

conjugation regulates exosome secretion(23). The accumulation of ACACA (Acetyl-CoA) (24)

and the other allosteric affected enzymes promote the de novo biogenesis, activation and channelling of fatty acids to synthesize TG in BMECs.

\section{Conclusions}

In this study, iTRAQ technology was used to demonstrate proteome spectrum changes in the BMECs after knocking down VPS28. It was concluded that VPS28 knockdown promotes 
288

289

290

291

292

293

294

295

296

297

298

299

300

301

302

303

304

305

306

307

308

309

310

milk fat synthesis in BMECs which might be attributed to differentially expressed proteins. The

DEPs enriched in gene ontology categories associated with ubiquitylation likely played an important role in the TG synthesis in BMECs. The dysfunctional proteasome, accumulation of

TG might explain the regulation of VPS28 on milk fat synthesis was mediated by ubiquitylation.

Our results provide a comprehensive dataset of ubiquitylation regulating milk fat synthesis, and also provide a reference for the further study of ubiquitination in dairy breeding.

\section{Acknowledgements}

This work was financially supported by the National Natural Science Foundations of China (31902152), the National Major Development Program of Transgenic Breeding (2014ZX0800953B), the National Natural Science Foundations of China (31201772), the National Science and Technology Programs of China (2013AA102504).The funders had no roles in the study design, data collection and analysis, decision to publish or preparation of the manuscript.

\section{Reference}

1. H. Teo, D. J. Gill, J. Sun, O. Perisic, D. B. Veprintsev, Y. Vallis, S. D. Emr, R. L. Williams, ESCRT-I core and ESCRT-II GLUE domain structures reveal role for GLUE in linking to ESCRT-I and membranes. Cell 125, 99-111 (2006); published online EpubApr 7 (10.1016/j.cell.2006.01.047).

2. E. Pineda-Molina, H. Belrhali, A. J. Piefer, I. Akula, P. Bates, W. Weissenhorn, The crystal structure of the C-terminal domain of Vps28 reveals a conserved surface required for Vps20 recruitment. Traffic 7, 1007-1016 (2006); published online EpubAug (10.1111/j.16000854.2006.00440.x).

3. S. Saksena, J. Sun, T. Chu, S. D. Emr, ESCRTing proteins in the endocytic pathway. 
311 Trends in biochemical sciences 32, 561-573 (2007); published online EpubDec

312 (10.1016/j.tibs.2007.09.010).

313 4. C. K. Raymond, I. Howald-Stevenson, C. A. Vater, T. H. Stevens, Morphological

314 classification of the yeast vacuolar protein sorting mutants: evidence for a prevacuolar

315 compartment in class E vps mutants. Molecular biology of the cell 3, 1389-1402 (1992);

316 published online EpubDec (10.1091/mbc.3.12.1389).

317 5. A. Ciechanover, The ubiquitin-proteasome proteolytic pathway. Cell 79, 13-21 (1994);

318 published online EpubOct 7 (10.1016/0092-8674(94)90396-4).

319 6. D. J. Katzmann, M. Babst, S. D. Emr, Ubiquitin-dependent sorting into the

320 multivesicular body pathway requires the function of a conserved endosomal protein sorting

321 complex, ESCRT-I. Cell 106, 145-155 (2001); published online EpubJul 27 (10.1016/s0092-

$3228674(01) 00434-2)$.

323

324

325

7. N. Bishop, A. Horman, P. Woodman, Mammalian class E vps proteins recognize ubiquitin and act in the removal of endosomal protein-ubiquitin conjugates. The Journal of cell biology 157, 91-101 (2002); published online EpubApr 1 (10.1083/jcb.200112080).

8. L. L. Liu, A. W. Guo, P. F. Wu, F. F. Chen, Y. J. Yang, Q. Zhang, [Regulation of VPS28 gene knockdown on the milk fat synthesis in Chinese Holstein dairy]. Yi chuan = Hereditas 40, 1092-1100 (2018); published online EpubDec 20 (10.16288/j.yczz.18-134).

9. L. Liu, Q. Zhang, Identification and functional analysis of candidate gene VPS28 for milk fat in bovine mammary epithelial cells. Biochemical and biophysical research communications 510, 606-613 (2019); published online EpubMar 19 (10.1016/j.bbrc.2019.01.016).

10. L. Jiang, J. Liu, D. Sun, P. Ma, X. Ding, Y. Yu, Q. Zhang, Genome wide association studies for milk production traits in Chinese Holstein population. Plos One 5, e13661 (2010); published online EpubOct 27 (10.1371/journal.pone.0013661).

11. L. Jiang, X. Liu, J. Yang, H. F. Wang, J. C. Jiang, L. L. Liu, S. He, X. D. Ding, J. F. Liu, Q. Zhang, Targeted resequencing of GWAS loci reveals novel genetic variants for milk 
338

339

340

341

342

343

344

345

346

347

348

349

350

351

352

353

354

355

356

357

358

359

360

361

362

363

364

production traits. BMC genomics 15, (2014); published online EpubDec 15 (Artn 1105

Doi 10.1186/1471-2164-15-1105).

12. Q. Z. Lily Liu, Identification and functional analysis of candidate gene VPS28 for milk

fat in bovine mammary epithelial cells. Biochemical and biophysical research communications, 510(4):606-613 (2019). Epub 2019 Feb 8. (doi: 10.1016/j.bbrc.2019.01.016).

13. D. Hoeller, I. Dikic, Targeting the ubiquitin system in cancer therapy. Nature 458, 438444 (2009); published online EpubMar 26 (10.1038/nature07960).

14. J. Smith, X. Su, R. El-Maghrabi, P. D. Stahl, N. A. Abumrad, Opposite regulation of CD36 ubiquitination by fatty acids and insulin: effects on fatty acid uptake. The Journal of biological chemistry 283, 13578-13585 (2008); published online EpubMay 16 (10.1074/jbc.M800008200).

15. B. H. J. Chang, L. Chan, Regulation of triglyceride metabolism. III. Emerging role of lipid droplet protein ADFP in health and disease. Am J Physiol-Gastr L 292, G1465-G1468 (2007); published online EpubJun (10.1152/ajpgi.00566.2006).

16. C. P. Liang, S. Han, H. Okamoto, R. Carnemolla, I. Tabas, D. Accili, A. R. Tall, Increased CD36 protein as a response to defective insulin signaling in macrophages. The Journal of clinical investigation 113, 764-773 (2004); published online EpubMar (10.1172/JCI19528).

17. E. K. Schrader, K. G. Harstad, A. Matouschek, Targeting proteins for degradation. Nature chemical biology 5, 815-822 (2009); published online EpubNov (10.1038/nchembio.250). 18. C. A. Lamb, R. K. McCann, J. Stockli, D. E. James, N. J. Bryant, Insulin-regulated trafficking of GLUT4 requires ubiquitination. Traffic 11, 1445-1454 (2010); published online EpubNov (10.1111/j.1600-0854.2010.01113.x).

19. I. U. Haq, Y. Han, T. Ali, Y. Wang, H. Gao, L. Lin, Y. Wu, S. Wu, S. Zeng, Expression of interferon-stimulated gene ISG15 and ubiquitination enzymes is upregulated in peripheral blood monocyte during early pregnancy in dairy cattle. Reproductive biology 16, 255-260 (2016); published online EpubDec (10.1016/j.repbio.2016.10.001).

20. X. Zhou, J. Wei, F. Chen, X. Xiao, T. Huang, Q. He, S. Wang, C. Du, Y. Mo, L. Lin, Y. 
365

366

367

368

369

370

371

372

373

374

375

376

377

378

379

380

381
Xie, L. Wei, Y. Lan, M. Murata, G. Huang, I. Ernberg, L. Matskova, Z. Zhang, Epigenetic downregulation of the ISG15-conjugating enzyme UbcH8 impairs lipolysis and correlates with poor prognosis in nasopharyngeal carcinoma. Oncotarget 6, 41077-41091 (2015); published online EpubDec 01 (10.18632/oncotarget.6218).

21. K. I. Kim, N. V. Giannakopoulos, H. W. Virgin, D. E. Zhang, Interferon-inducible ubiquitin E2, Ubc8, is a conjugating enzyme for protein ISGylation. Mol Cell Biol 24, 9592-9600 (2004); published online EpubNov (10.1128/MCB.24.21.9592-9600.2004).

22. C. Zhao, S. L. Beaudenon, M. L. Kelley, M. B. Waddell, W. Yuan, B. A. Schulman, J. M. Huibregtse, R. M. Krug, The UbcH8 ubiquitin E2 enzyme is also the E2 enzyme for ISG15, an IFN-alpha/beta-induced ubiquitin-like protein. Proc Natl Acad Sci U S A 101, 7578-7582 (2004); published online EpubMay 18 (10.1073/pnas.0402528101).

23. C. Villarroya-Beltri, F. Baixauli, M. Mittelbrunn, I. Fernandez-Delgado, D. Torralba, O. Moreno-Gonzalo, S. Baldanta, C. Enrich, S. Guerra, F. Sanchez-Madrid, ISGylation controls exosome secretion by promoting lysosomal degradation of MVB proteins. Nature communications 7, 13588 (2016); published online EpubNov 24 (10.1038/ncomms13588). 24. R. S. Emery, Biosynthesis Of Milk-Fat. Journal of dairy science 56, 1187-1195 (1973). 
Figure 1

Effects of VPS28 knockdown on BMECs.

A: The mRNA expression of VPS28 was decreased by tandem siRNAs constructs. B and C: Electron micrographs of BMECs. D: The TG content was significantly increased in VPS28 knockdown BMEC. Data are averages of three replicates. The error or bars denote SEM. * indicates the difference is significant $(P \leq 0.05)$. 
A

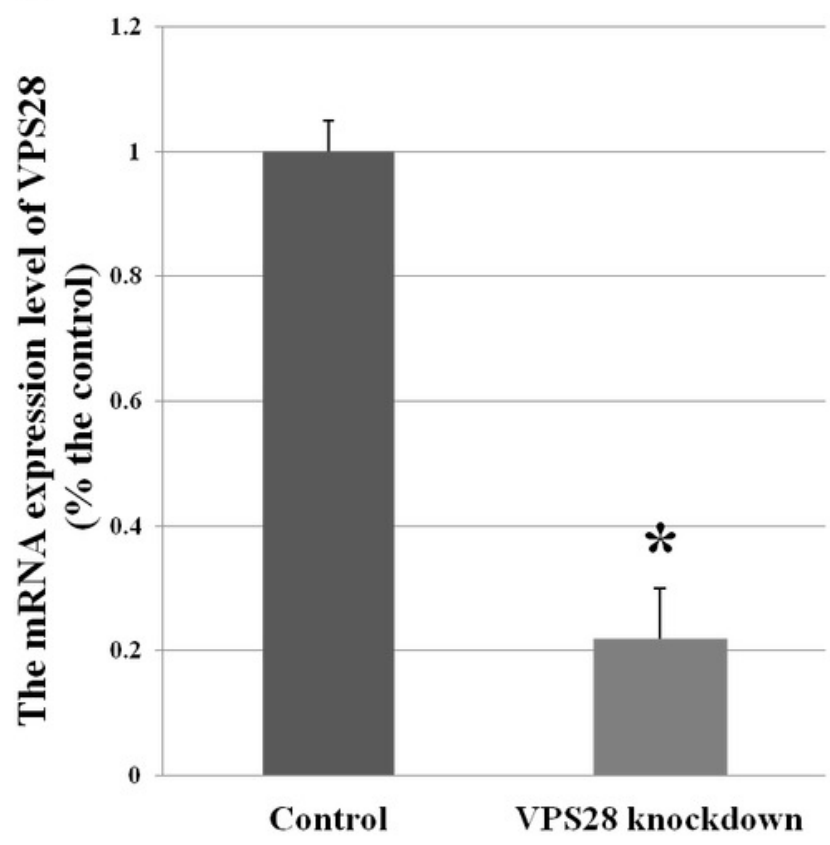

\section{B : Control}

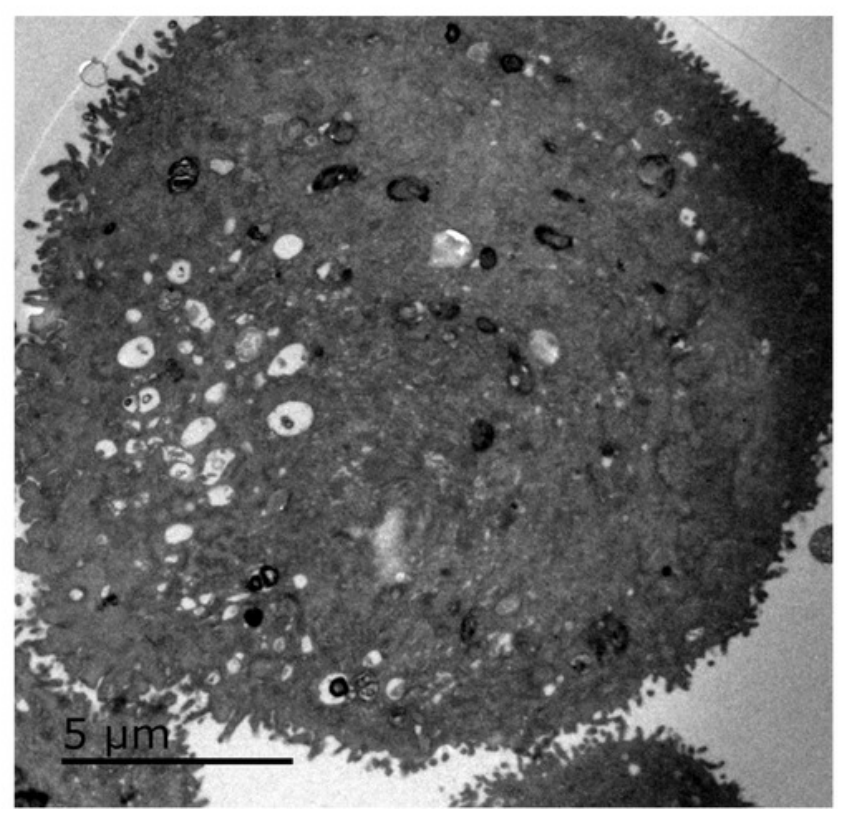

D

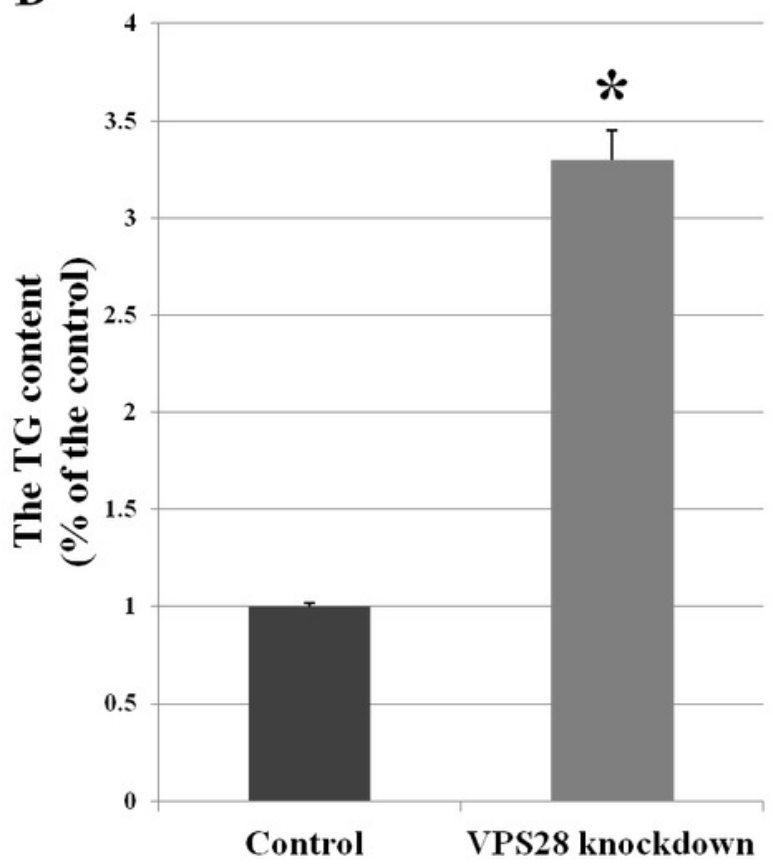

C: VPS28 knockdown

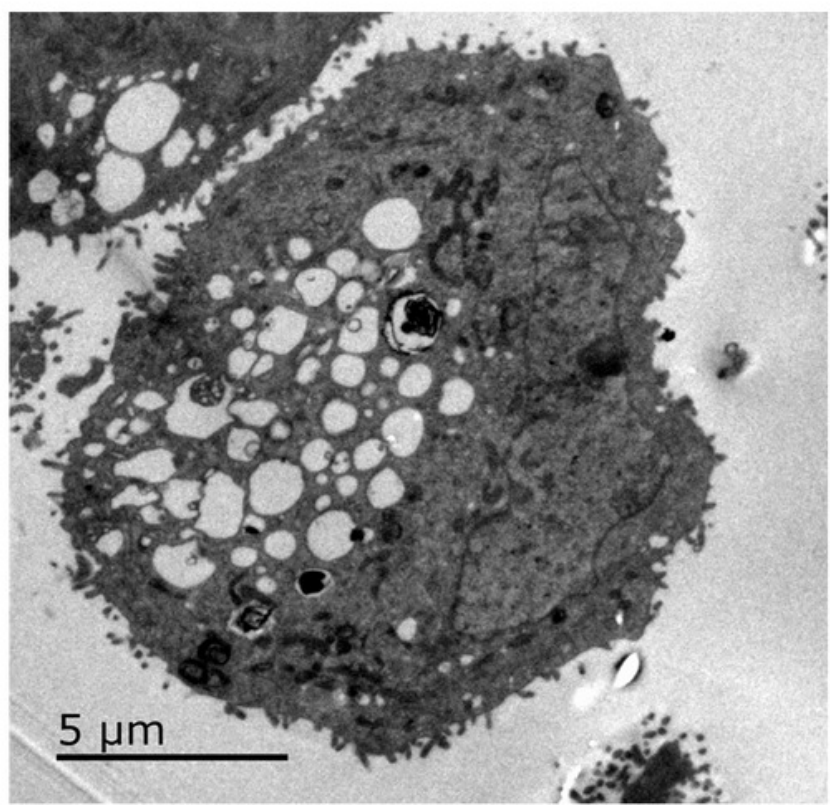




\section{Figure 2}

The proteasome activity was decreased by VPS28 knockdown.

Chymotreypsin-like activity, caspase-like activity and trypsin-like activity are the three activities in proteasome. ${ }^{*}$ indicates the difference is significant $(P \leq 0.05)$.

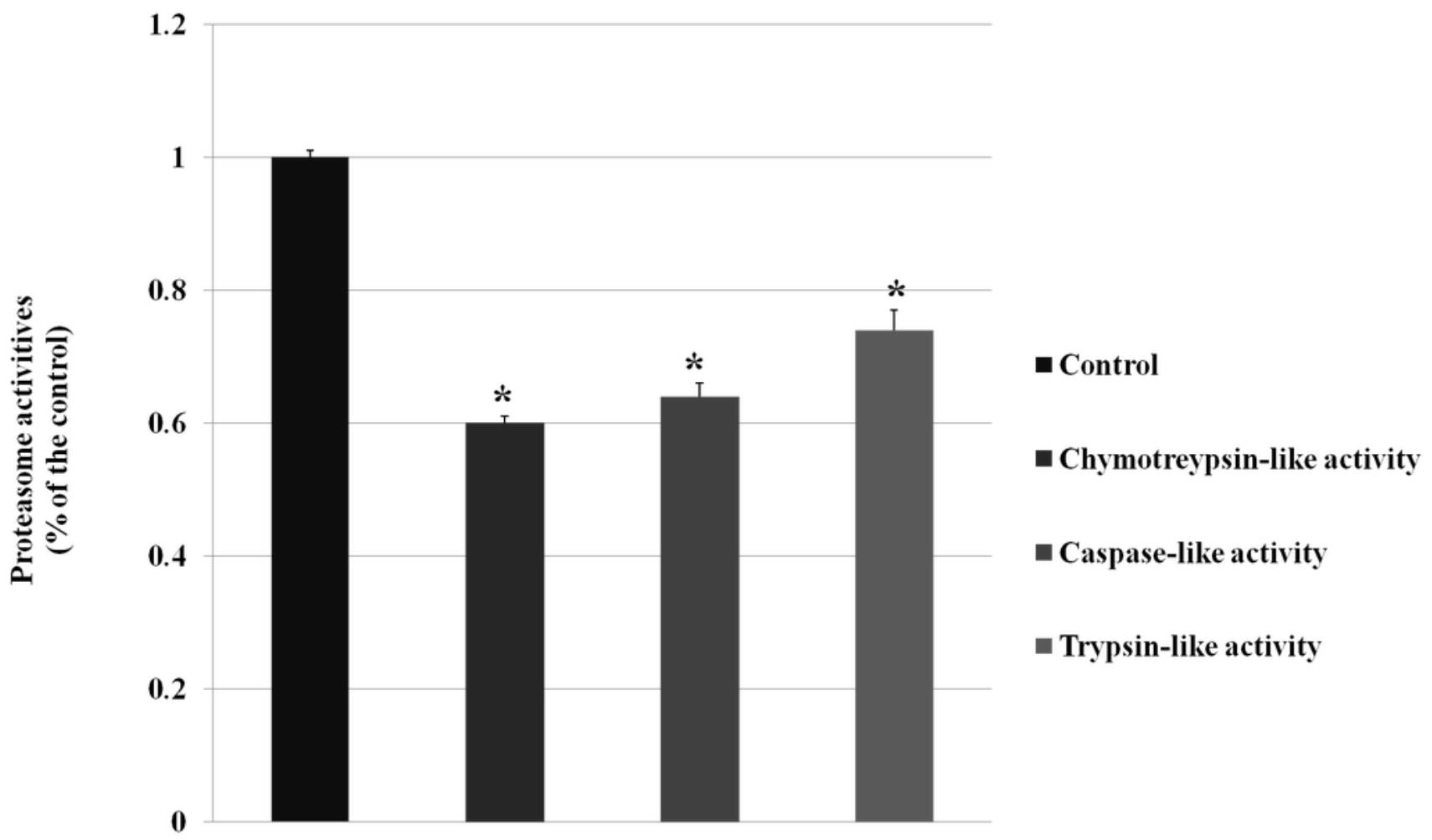


Figure 3

The mRNA expression of selected genes in VPS28 knockdown BMECs.

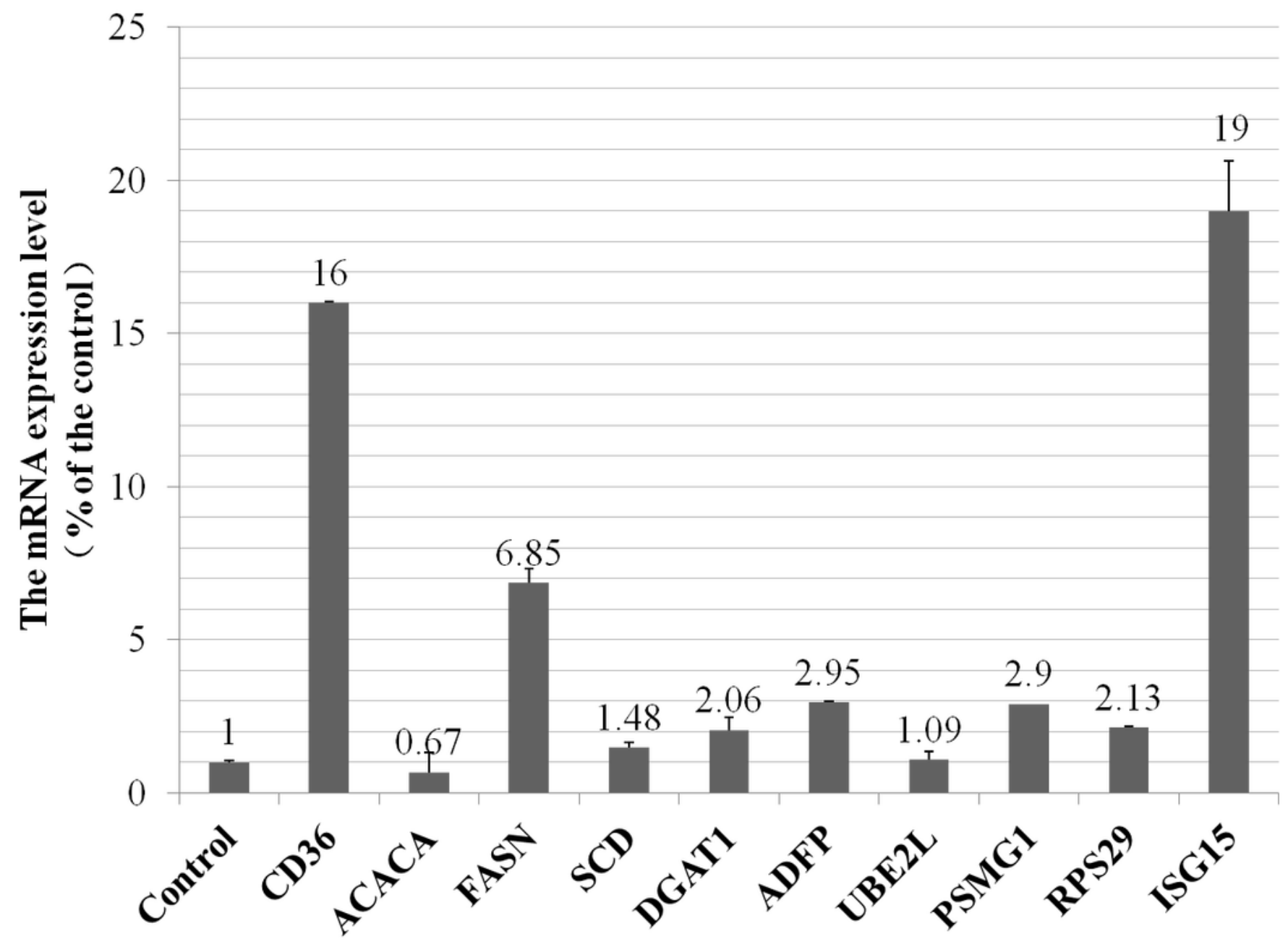


Figure 4

The network of VPS28 knockdown regulates milk fat synthesis in BMECs.

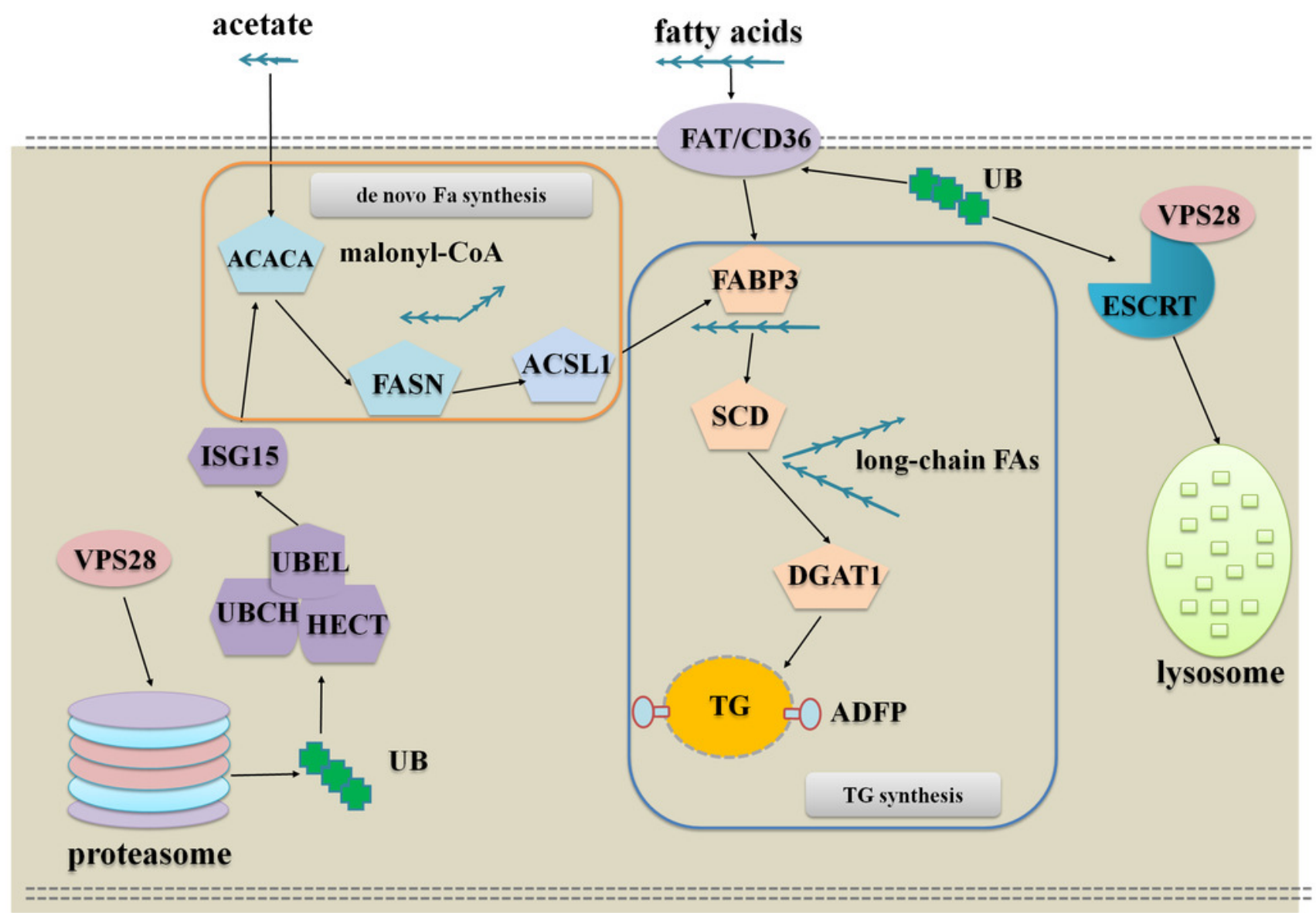


Table $\mathbf{1}$ (on next page)

Differentially expressed proteins following VPS28 knockdown in BMEC. 
1 Table 1. Primers of the selected genes for $q$ RT-PCR and their relative expression.

\begin{tabular}{|c|c|c|}
\hline Genes & Primer sequences $\left(5^{\prime} \rightarrow 3^{\prime}\right)$ & Relative expression \\
\hline \multirow[t]{2}{*}{ GAPDH } & AGATGGTGAAGGTCGGAGTG & / \\
\hline & CGTTCTCTGCCTTGACTGTG & \\
\hline \multirow[t]{2}{*}{ VPS28 } & GGAAACAAGCCGGAGCTGTA & 0.22 \\
\hline & CTGGATCTCGTCCATGGCTC & \\
\hline \multirow[t]{2}{*}{ CD36 } & GACGGATGTACAGCGGTGAT & 16.00 \\
\hline & GAAAAAGTGCAAGGCCACCA & \\
\hline \multirow[t]{2}{*}{$A C A C A$} & AGTGTTCTGATCAGGTCTTCTTGT & 0.67 \\
\hline & GGGAGGCAAAAACCTCCAGA & \\
\hline \multirow[t]{2}{*}{$F A S N$} & AGGCGTGCGTGACACTT & 6.85 \\
\hline & AATACAGTTGGCCGTCACCA & \\
\hline \multirow[t]{2}{*}{$S C D$} & TCCTGATCATTGGCAACACCA & 1.48 \\
\hline & CCAACCCACGTGAGAGAAGAA & \\
\hline \multirow[t]{2}{*}{$D G A T 1$} & TACCCCGACAACCTGACCTA & 2.06 \\
\hline & GGGAAGTTGAGCTCGTAGCA & \\
\hline \multirow[t]{2}{*}{$A D F P$} & GCGTCTGCTGGCTGATTTC & 2.95 \\
\hline & AGCCGAGGAGACCAGATCATA & \\
\hline \multirow[t]{2}{*}{ PSMG1 } & GGGAAGAAGTCGGTTGTGCT & 2.87 \\
\hline & AAAAAGCCTCTGTGGGGGAC & \\
\hline \multirow[t]{2}{*}{$U B E 2 L$} & CTGGCACAGTATATGAAGACCTGA & 1.28 \\
\hline & GGTAGCAGGGTGTGAGGAAC & \\
\hline \multirow[t]{2}{*}{ RPS29 } & TGTTTCCGCCAGTATGCGAA & 2.13 \\
\hline & GCTGGATGAGCCATCTAAGGAA & \\
\hline \multirow[t]{2}{*}{ ISG15 } & CCATCCTGGTGAGGAACGAC & 19.02 \\
\hline & GTCTGCTTGTACACGCTCCT & \\
\hline
\end{tabular}

2

3

4 


\section{Table 2 (on next page)}

Gene ontology analysis of differentally expressed proteins in VPS28 knockdown BMECs. 
1 Table 2. Differentially expressed proteins following VPS28 knockdown in BMEC.

\begin{tabular}{|c|c|c|}
\hline Accession & Description & RATIO \\
\hline 300796460 & pescadillo homolog & 0.79 \\
\hline 333440457 & immortalization up-regulated protein & 1.38 \\
\hline 528937065 & $\begin{array}{l}\text { PREDICTED: fragile } \mathrm{X} \text { mental retardation syndrome-related } \\
\text { protein } 1 \text { isoform } \mathrm{X} 6\end{array}$ & 0.83 \\
\hline 741896620 & PREDICTED: bifunctional coenzyme A synthase isoform X2 & 1.25 \\
\hline 741972182 & PREDICTED: serpin B8 isoform $\mathrm{X} 1$ & 1.33 \\
\hline 359069079 & $\begin{array}{l}\text { PREDICTED: apoptotic chromatin condensation inducer in the } \\
\text { nucleus isoform X5 }\end{array}$ & 0.74 \\
\hline 528978576 & PREDICTED: lysosomal acid phosphatase isoform X3 & 0.8 \\
\hline 77736117 & actin, alpha cardiac muscle 1 & 1.33 \\
\hline 741976470 & $\begin{array}{l}\text { PREDICTED: actin filament-associated protein 1-like } 2 \\
\text { isoform X5 }\end{array}$ & 0.82 \\
\hline 156120791 & A-kinase anchor protein 8 & 0.62 \\
\hline 155371939 & putative N-acetylglucosamine-6-phosphate deacetylase & 1.23 \\
\hline 741911242 & PREDICTED: AP-2 complex subunit sigma-like & 0.82 \\
\hline 115496866 & AP-3 complex subunit beta- 1 & 1.22 \\
\hline 75832056 & apolipoprotein A-I preproprotein & 0.46 \\
\hline 114052298 & apolipoprotein A-II precursor & 0.55 \\
\hline 741944057 & PREDICTED: apolipoprotein B-100 isoform X3 & 0.71 \\
\hline 27806739 & apolipoprotein E precursor & 0.34 \\
\hline 51491835 & ovarian and testicular apolipoprotein $\mathrm{N}$ precursor & 0.61 \\
\hline 528973530 & $\begin{array}{l}\text { PREDICTED: ADP-ribosylation factor GTPase-activating } \\
\text { protein } 1 \text { isoform X3 }\end{array}$ & 0.8 \\
\hline 300798482 & rho GTPase-activating protein 35 & 1.36 \\
\hline 329664977 & AT-rich interactive domain-containing protein $1 \mathrm{~A}$ & 0.83 \\
\hline 529009701 & PREDICTED: acid ceramidase isoform X1 & 1.62 \\
\hline 329663402 & ATPase family AAA domain-containing protein 1 & 0.76 \\
\hline 741980112 & PREDICTED: atlastin-3 isoform $\mathrm{X} 1$ & 0.83 \\
\hline 60101829 & ATP synthase subunit 8 (mitochondrion) & 1.24 \\
\hline 28603752 & ATP synthase subunit e, mitochondrial & 0.63 \\
\hline 116004323 & ataxin-10 & 0.83 \\
\hline 41386683 & beta-2-microglobulin precursor & 0.82 \\
\hline 84000125 & B-cell receptor-associated protein 29 & 1.34 \\
\hline 27806229 & $\begin{array}{l}\text { 2-oxoisovalerate dehydrogenase subunit alpha, mitochondrial } \\
\text { precursor }\end{array}$ & 0.83 \\
\hline 741929024 & PREDICTED: uncharacterized protein C4orf3 homolog & 1.35 \\
\hline
\end{tabular}




\begin{tabular}{|c|c|c|}
\hline & isoform $\mathrm{X} 1$ & \\
\hline 741945468 & PREDICTED: calcium-binding protein 39-like isoform X1 & 0.79 \\
\hline 45439308 & CD63 antigen & 1.36 \\
\hline 78042548 & CD81 antigen & 1.25 \\
\hline 741967799 & $\begin{array}{l}\text { PREDICTED: LOW QUALITY PROTEIN: serine/threonine- } \\
\text { protein kinase MRCK beta isoform X2 }\end{array}$ & 1.37 \\
\hline 529002260 & PREDICTED: CUB domain-containing protein 1 & 0.8 \\
\hline 77735577 & CCR4-NOT transcription complex subunit 7 & 0.77 \\
\hline 741922497 & PREDICTED: collagen alpha-3(VI) chain isoform X7 & 0.81 \\
\hline 114052042 & COMM domain-containing protein 1 & 1.23 \\
\hline 741945876 & $\begin{array}{l}\text { PREDICTED: COMM domain-containing protein } 6 \text { isoform } \\
\qquad \mathrm{X} 2\end{array}$ & 0.68 \\
\hline 528966533 & $\begin{array}{l}\text { PREDICTED: COP9 signalosome complex subunit } 2 \text { isoform } \\
\qquad \mathrm{X} 1\end{array}$ & 0.82 \\
\hline 149642865 & COP9 signalosome complex subunit 3 & 0.74 \\
\hline 330688478 & crooked neck-like protein 1 & 1.6 \\
\hline 262073106 & cathepsin D precursor & 1.23 \\
\hline 118151448 & CUGBP Elav-like family member 2 & 1.25 \\
\hline 741917150 & PREDICTED: cytochrome P450 20A1 isoform X1 & 1.27 \\
\hline 164420721 & dynactin subunit 5 & 1.29 \\
\hline 528937089 & PREDICTED: DCN1-like protein 1 isoform $\mathrm{X} 1$ & 0.67 \\
\hline 149642575 & ATP-dependent RNA helicase DDX24 & 1.54 \\
\hline 114051872 & density-regulated protein & 0.81 \\
\hline 157427916 & H/ACA ribonucleoprotein complex subunit 4 & 1.22 \\
\hline 115497846 & deoxyhypusine hydroxylase & 1.48 \\
\hline 528989517 & $\begin{array}{l}\text { PREDICTED: developmentally-regulated GTP-binding protein } \\
\qquad 1 \text { isoform X1 }\end{array}$ & 1.47 \\
\hline 114051994 & dysbindin & 1.35 \\
\hline 329663806 & cytoplasmic dynein 1 light intermediate chain 2 & 1.23 \\
\hline 56710336 & dynein light chain 1 , cytoplasmic & 0.83 \\
\hline 77735949 & 3-beta-hydroxysteroid-Delta(8),Delta(7)-isomerase & 1.24 \\
\hline 62751595 & translation initiation factor eIF-2B subunit beta & 0.71 \\
\hline 300794424 & eukaryotic translation initiation factor 5 & 0.78 \\
\hline 329664532 & ephrin type-A receptor 2 precursor & 0.74 \\
\hline 77735625 & enhancer of rudimentary homolog & 0.81 \\
\hline 27806943 & coagulation factor $\mathrm{V}$ precursor & 0.81 \\
\hline 528957418 & PREDICTED: protein FAM114A2 isoform X1 & 1.29 \\
\hline 329663573 & protein FAM134A & 0.75 \\
\hline
\end{tabular}




\begin{tabular}{|c|c|c|}
\hline 359069460 & PREDICTED: protein FAM98B & 0.8 \\
\hline 29135293 & farnesyl pyrophosphate synthase & 0.77 \\
\hline 77736507 & mitochondrial fission 1 protein & 1.27 \\
\hline 156718120 & fat storage-inducing transmembrane protein 2 & 1.23 \\
\hline 27806621 & ferritin heavy chain & 0.8 \\
\hline 114051796 & glucosylceramidase precursor & 0.81 \\
\hline 84000253 & glutamate--cysteine ligase regulatory subunit & 1.21 \\
\hline 114051291 & GDP-L-fucose synthase & 0.78 \\
\hline 741919465 & PREDICTED: lysosomal protein NCU-G1 isoform X2 & 0.81 \\
\hline 115496402 & glucosamine-6-phosphate isomerase 2 & 0.83 \\
\hline 297488836 & PREDICTED: histone $\mathrm{H} 1 \mathrm{x}$ & 0.82 \\
\hline 116812902 & hemoglobin subunit alpha & 0.55 \\
\hline 17985949 & hemoglobin subunit beta-1 [Rattus norvegicus] & 1.23 \\
\hline 741905547 & PREDICTED: host cell factor 1 isoform X9 & 1.26 \\
\hline 114052627 & hepatocyte growth factor-regulated tyrosine kinase substrate & 1.21 \\
\hline 134085671 & histone $\mathrm{H} 1.2$ & 0.55 \\
\hline 155371863 & histone $\mathrm{H} 1.3$ & 0.54 \\
\hline 741971316 & PREDICTED: histone H2A type 1-J & 1.29 \\
\hline 157785601 & histone $\mathrm{H} 2 \mathrm{~B}$ & 0.82 \\
\hline 115496175 & high mobility group protein HMG-I/HMG-Y & 0.8 \\
\hline 77736489 & non-histone chromosomal protein HMG-14 & 0.79 \\
\hline 297477251 & PREDICTED: heterogeneous nuclear ribonucleoprotein A0 & 0.83 \\
\hline 375364520 & HCLS1-binding protein 3 & 1.48 \\
\hline 41386699 & heat shock-related $70 \mathrm{kDa}$ protein 2 & 1.23 \\
\hline 529014943 & PREDICTED: immunoglobulin-binding protein 1 isoform $\mathrm{X} 2$ & 1.23 \\
\hline 27805955 & ubiquitin-like protein ISG15 & 0.83 \\
\hline 157427772 & involucrin & 1.25 \\
\hline 195539527 & keratin 15 & 1.24 \\
\hline 77736483 & ragulator complex protein LAMTOR1 & 0.82 \\
\hline 741894288 & PREDICTED: galectin-7 & 1.26 \\
\hline 528952868 & $\begin{array}{l}\text { PREDICTED: LIM and calponin homology domains- } \\
\text { containing protein } 1 \text { isoform X5 }\end{array}$ & 1.36 \\
\hline 115497506 & LIM and cysteine-rich domains protein 1 & 1.23 \\
\hline 686713724 & $\begin{array}{l}\text { PREDICTED: LOW QUALITY PROTEIN: collagen alpha- } \\
\text { 4(VI) chain-like, partial [Pongo abelii] }\end{array}$ & 0.72 \\
\hline 741878073 & PREDICTED: N-acylneuraminate cytidylyltransferase & 1.96 \\
\hline 741946731 & $\begin{array}{c}\text { PREDICTED: ankyrin repeat domain-containing protein 26- } \\
\text { like isoform X2 }\end{array}$ & 0.35 \\
\hline
\end{tabular}




\begin{tabular}{|c|c|c|}
\hline 62460494 & hemoglobin fetal subunit beta & 0.56 \\
\hline 84000167 & WD repeat-containing protein 61 & 1.36 \\
\hline 741960002 & $\begin{array}{l}\text { PREDICTED: protein arginine N-methyltransferase } 1 \text { isoform } \\
\qquad \mathrm{X} 2\end{array}$ & 0.76 \\
\hline 297483902 & PREDICTED: apolipoprotein $\mathrm{R}$ & 0.61 \\
\hline 155372051 & tropomyosin alpha-4 chain & 0.83 \\
\hline 78369240 & U6 snRNA-associated Sm-like protein LSm4 & 0.7 \\
\hline 122692397 & latexin & 0.79 \\
\hline 77735445 & protein mago nashi homolog & 1.22 \\
\hline 741939300 & $\begin{array}{l}\text { PREDICTED: dual specificity mitogen-activated protein } \\
\text { kinase kinase } 1 \text { isoform } \mathrm{X} 1\end{array}$ & 1.21 \\
\hline 528995215 & $\begin{array}{l}\text { PREDICTED: dual specificity mitogen-activated protein } \\
\text { kinase kinase } 4 \text { isoform } \mathrm{X} 2\end{array}$ & 1.21 \\
\hline 741898851 & $\begin{array}{c}\text { PREDICTED: MAP/microtubule affinity-regulating kinase } 3 \\
\text { isoform X1, partial }\end{array}$ & 0.83 \\
\hline 528957564 & $\begin{array}{c}\text { PREDICTED: methionine adenosyltransferase } 2 \text { subunit beta } \\
\text { isoform } \mathrm{X} 1\end{array}$ & 0.81 \\
\hline 528966905 & PREDICTED: protein max isoform $\mathrm{X} 2$ & 0.76 \\
\hline 741957547 & $\begin{array}{l}\text { PREDICTED: mediator of RNA polymerase II transcription } \\
\text { subunit } 15 \text { isoform X3 }\end{array}$ & 0.79 \\
\hline 300794942 & DNA mismatch repair protein Msh6 & 0.74 \\
\hline 27806841 & interferon-induced GTP-binding protein $\mathrm{Mx} 1$ & 0.73 \\
\hline 528936325 & PREDICTED: N-alpha-acetyltransferase 50 isoform X1 & 1.3 \\
\hline 375065860 & NAD kinase 2, mitochondrial & 1.29 \\
\hline 300795748 & NEDD8-activating enzyme E1 regulatory subunit & 0.77 \\
\hline 331284195 & nucleolin & 1.38 \\
\hline 78369204 & protein NDRG2 & 1.24 \\
\hline 28372495 & $\begin{array}{c}\text { NADH dehydrogenase [ubiquinone] } 1 \text { alpha subcomplex } \\
\text { subunit } 11\end{array}$ & 1.23 \\
\hline 75812936 & $\begin{array}{l}\text { NADH dehydrogenase [ubiquinone] } 1 \text { beta subcomplex } \\
\text { subunit } 11 \text {, mitochondrial precursor }\end{array}$ & 1.32 \\
\hline 28603776 & $\begin{array}{l}\text { NADH dehydrogenase [ubiquinone] } 1 \text { beta subcomplex } \\
\text { subunit } 5 \text {, mitochondrial precursor }\end{array}$ & 0.72 \\
\hline 528944090 & PREDICTED: nexilin isoform X5 & 0.76 \\
\hline 300794221 & nuclear protein localization protein 4 homolog & 0.82 \\
\hline 83035119 & nuclear transport factor 2 & 0.79 \\
\hline 741958202 & PREDICTED: prolyl 3-hydroxylase OGFOD1 isoform X1 & 0.65 \\
\hline 27807193 & platelet-activating factor acetylhydrolase IB subunit beta & 1.27 \\
\hline
\end{tabular}




\begin{tabular}{|c|c|c|}
\hline 75812940 & phosphatidylethanolamine-binding protein 1 & 1.27 \\
\hline 528913445 & $\begin{array}{l}\text { PREDICTED: presequence protease, mitochondrial isoform } \\
\qquad \mathrm{X} 2\end{array}$ & 1.21 \\
\hline 329664500 & pyruvate kinase PKM & 1.25 \\
\hline 528961976 & PREDICTED: pyruvate kinase PKM isoform X1 & 1.26 \\
\hline 741932605 & PREDICTED: perilipin-3 isoform $\mathrm{X} 3$ & 0.82 \\
\hline 116004039 & peptidyl-prolyl cis-trans isomerase $\mathrm{C}$ precursor & 1.22 \\
\hline 741957590 & PREDICTED: protein phosphatase $1 \mathrm{~F}$ & 1.53 \\
\hline 115497768 & relA-associated inhibitor & 1.24 \\
\hline 528943961 & $\begin{array}{c}\text { PREDICTED: cAMP-dependent protein kinase catalytic } \\
\text { subunit beta isoform X8 }\end{array}$ & 1.22 \\
\hline 741948151 & PREDICTED: pre-mRNA-processing factor 6 isoform X1 & 0.73 \\
\hline 115496548 & proteasome assembly chaperone 1 & 1.26 \\
\hline 741926509 & PREDICTED: prostaglandin E synthase 3 isoform $\mathrm{X} 1$ & 0.83 \\
\hline 157428086 & ras-related protein $\mathrm{Rab}-8 \mathrm{~A}$ & 0.8 \\
\hline 77736231 & ras-related protein Ral-A & 1.2 \\
\hline 56118252 & RING finger protein $113 \mathrm{~A}$ & 1.27 \\
\hline 741937627 & $\begin{array}{l}\text { PREDICTED: ribosome production factor } 2 \text { homolog isoform } \\
\qquad \mathrm{X} 1\end{array}$ & 0.77 \\
\hline 27807465 & $60 \mathrm{~S}$ ribosomal protein $\mathrm{L} 10$ & 0.79 \\
\hline 62751646 & $60 \mathrm{~S}$ ribosomal protein $\mathrm{L} 13$ & 0.7 \\
\hline 116004215 & $60 \mathrm{~S}$ ribosomal protein $\mathrm{L} 13 \mathrm{a}$ & 0.81 \\
\hline 118150852 & $60 \mathrm{~S}$ ribosomal protein $\mathrm{L} 15$ & 0.7 \\
\hline 62751887 & 60 S ribosomal protein $\mathrm{L} 26$ & 0.77 \\
\hline 77404275 & 60 S ribosomal protein $\mathrm{L} 27$ & 0.79 \\
\hline 77735585 & 60 S ribosomal protein $\mathrm{L} 36 \mathrm{a}$ & 0.8 \\
\hline 62460480 & 60 S ribosomal protein $\mathrm{L} 4$ & 0.74 \\
\hline 114053031 & 39S ribosomal protein L48, mitochondrial precursor & 0.81 \\
\hline 72534798 & 60 S ribosomal protein $\mathrm{L} 6$ & 0.72 \\
\hline 62460552 & $60 \mathrm{~S}$ ribosomal protein $\mathrm{L} 7$ & 0.77 \\
\hline 77736197 & $60 \mathrm{~S}$ ribosomal protein $\mathrm{L} 8$ & 0.78 \\
\hline 164420694 & 60S ribosomal protein L9 & 1.21 \\
\hline 70778762 & $60 \mathrm{~S}$ acidic ribosomal protein $\mathrm{P} 1$ & 1.2 \\
\hline 66792924 & $40 \mathrm{~S}$ ribosomal protein $\mathrm{S} 11$ & 0.76 \\
\hline 77735975 & 28S ribosomal protein S26, mitochondrial precursor & 1.23 \\
\hline 528994013 & $\begin{array}{c}\text { PREDICTED: 28S ribosomal protein S23, mitochondrial } \\
\text { isoform } \mathrm{X} 3\end{array}$ & 1.23 \\
\hline 27807381 & $40 \mathrm{~S}$ ribosomal protein $\mathrm{S} 29$ & 1.23 \\
\hline
\end{tabular}




\begin{tabular}{|c|c|c|}
\hline 70778956 & $40 \mathrm{~S}$ ribosomal protein $\mathrm{S} 8$ & 0.79 \\
\hline 155372029 & $40 \mathrm{~S}$ ribosomal protein $\mathrm{S} 9$ & 0.69 \\
\hline 741947465 & PREDICTED: ribosome-binding protein 1 isoform $\mathrm{X} 2$ & 1.31 \\
\hline 300798287 & sec1 family domain-containing protein 1 & 0.83 \\
\hline 115497454 & protein SEC13 homolog & 1.28 \\
\hline 300794266 & SEC23-interacting protein & 1.3 \\
\hline 741978352 & PREDICTED: protein transport protein Sec $24 \mathrm{C}$ isoform $\mathrm{X} 2$ & 1.31 \\
\hline 115497008 & protein transport protein Sec61 subunit beta & 0.82 \\
\hline 70778796 & splicing factor $3 \mathrm{~B}$ subunit 5 & 1.3 \\
\hline 77736509 & S-phase kinase-associated protein 1 & 1.35 \\
\hline 82617542 & monocarboxylate transporter 1 & 1.24 \\
\hline 288557348 & SWI/SNF complex subunit SMARCC2 & 0.8 \\
\hline 115496404 & U1 small nuclear ribonucleoprotein $\mathrm{C}$ & 0.78 \\
\hline 329664862 & S1 RNA-binding domain-containing protein 1 & 0.73 \\
\hline 741921253 & $\begin{array}{l}\text { PREDICTED: serine/arginine-rich splicing factor } 11 \text { isoform } \\
\qquad \mathrm{X} 4\end{array}$ & 1.49 \\
\hline 329664840 & synaptopodin & 0.82 \\
\hline 84000143 & T-complex protein 1 subunit alpha & 1.21 \\
\hline 114051768 & tudor domain-containing protein 3 & 1.36 \\
\hline 300797062 & tudor domain-containing protein 6 & 1.52 \\
\hline 529000498 & $\begin{array}{l}\text { PREDICTED: THUMP domain-containing protein } 3 \text { isoform } \\
\qquad \mathrm{X} 1\end{array}$ & 1.3 \\
\hline 114326224 & tight junction protein $\mathrm{ZO}-3$ & 1.25 \\
\hline 300794719 & E3 ubiquitin-protein ligase TRIP12 & 0.78 \\
\hline 27806789 & transthyretin precursor & 1.29 \\
\hline 529005013 & PREDICTED: thioredoxin-like protein 1 isoform $\mathrm{X} 2$ & 1.21 \\
\hline 83035103 & ubiquitin-conjugating enzyme E2 H & 1.24 \\
\hline 528979920 & PREDICTED: ubiquitin conjugation factor $\mathrm{E} 4 \mathrm{~B}$ isoform $\mathrm{X} 1$ & 1.22 \\
\hline 114050863 & ubiquitin-like domain-containing CTD phosphatase 1 & 0.72 \\
\hline 529012185 & PREDICTED: UBX domain-containing protein 1 isoform X1 & 0.78 \\
\hline 62751620 & ubiquitin-fold modifier-conjugating enzyme 1 & 0.82 \\
\hline 529006388 & $\begin{array}{l}\text { PREDICTED: ubiquitin carboxyl-terminal hydrolase } 7 \text { isoform } \\
\qquad \mathrm{X} 2\end{array}$ & 1.37 \\
\hline 115496338 & vesicle-associated membrane protein-associated protein A & 1.2 \\
\hline 78369492 & vacuolar protein sorting-associated protein 28 homolog & 0.79 \\
\hline 78045497 & vitronectin precursor & 0.43 \\
\hline 741916372 & $\begin{array}{c}\text { PREDICTED: xin actin-binding repeat-containing protein } 2 \\
\text { isoform } \mathrm{X} 2\end{array}$ & 0.72 \\
\hline
\end{tabular}




\begin{tabular}{ccc}
\hline 126723764 & cap-specific mRNA (nucleoside-2'-O-)-methyltransferase 1 & 0.8 \\
78042540 & synaptobrevin homolog YKT6 & 0.82 \\
148224064 & transcriptional repressor protein YY1 & 0.76 \\
84370039 & zinc finger protein ZPR1 & 0.77 \\
528942220 & PREDICTED: rho guanine nucleotide exchange factor 2 & 1.2 \\
528962021 & isoform X5 & 0.83 \\
528979380 & PREDICTED: geranylgeranyl transferase type-2 subunit alpha & 1.35 \\
\hline
\end{tabular}

2 
Table 3 (on next page)

Primers of the selected genes for qRT-PCR and their relative expression. 
2 Table 3. Gene ontology analysis of differentally expressed proteins in VPS28 knockdown

3 BMECs.

\begin{tabular}{|c|c|c|}
\hline GO ID & Term & $P$ Value \\
\hline \multicolumn{3}{|c|}{ Biological Process } \\
\hline GO:0002181 & cytoplasmic translation & $3.60 \mathrm{E}-07$ \\
\hline GO: 0006412 & translation & $8.90 \mathrm{E}-07$ \\
\hline GO:0042632 & cholesterol homeostasis & $2.20 \mathrm{E}-03$ \\
\hline GO:0033344 & cholesterol efflux & 2.70E-03 \\
\hline GO:0010873 & positive regulation of cholesterol esterification & $2.80 \mathrm{E}-03$ \\
\hline GO:0034380 & high-density lipoprotein particle assembly & $3.70 \mathrm{E}-03$ \\
\hline GO:0000463 & maturation of LSU-rRNA from tricistronic rRNA transcript (SSU-rRNA, 5.8S & 4.70E-03 \\
\hline \multicolumn{3}{|c|}{ rRNA, LSU-rRNA) } \\
\hline GO:0043691 & reverse cholesterol transport & 7.10E-03 \\
\hline GO:0033700 & phospholipid efflux & $8.40 \mathrm{E}-03$ \\
\hline GO:0098779 & mitophagy in response to mitochondrial depolarization & $1.00 \mathrm{E}-02$ \\
\hline GO:0042157 & lipoprotein metabolic process & $1.30 \mathrm{E}-02$ \\
\hline GO:0019433 & triglyceride catabolic process & $1.50 \mathrm{E}-02$ \\
\hline GO:0006904 & vesicle docking involved in exocytosis & $2.30 \mathrm{E}-02$ \\
\hline GO:0000027 & ribosomal large subunit assembly & $2.30 \mathrm{E}-02$ \\
\hline GO:0018158 & protein oxidation & $2.30 \mathrm{E}-02$ \\
\hline GO:0006403 & RNA localization & $2.30 \mathrm{E}-02$ \\
\hline GO:0010628 & positive regulation of gene expression & $2.60 \mathrm{E}-02$ \\
\hline GO:0001843 & neural tube closure & $3.10 \mathrm{E}-02$ \\
\hline GO:0006695 & cholesterol biosynthetic process & $3.20 \mathrm{E}-02$ \\
\hline GO:0051028 & mRNA transport & $3.20 \mathrm{E}-02$ \\
\hline GO:0042921 & glucocorticoid receptor signaling pathway & $3.50 \mathrm{E}-02$ \\
\hline GO:0010903 & negative regulation of very-low-density lipoprotein particle remodeling & $3.50 \mathrm{E}-02$ \\
\hline GO:0006046 & $\mathrm{N}$-acetylglucosamine catabolic process & $3.50 \mathrm{E}-02$ \\
\hline GO:1901998 & toxin transport & $3.70 \mathrm{E}-02$ \\
\hline GO:0006888 & ER to Golgi vesicle-mediated transport & $3.80 \mathrm{E}-02$ \\
\hline GO:0018206 & peptidyl-methionine modification & $4.60 \mathrm{E}-02$ \\
\hline GO:0042159 & lipoprotein catabolic process & 4.60E-02 \\
\hline GO:0042158 & lipoprotein biosynthetic process & 4.60E-02 \\
\hline \multicolumn{3}{|c|}{ Cellular Component } \\
\hline GO:0022625 & cytosolic large ribosomal subunit & $4.00 \mathrm{E}-12$ \\
\hline GO:0070062 & extracellular exosome & $2.70 \mathrm{E}-08$ \\
\hline GO:0005925 & focal adhesion & $1.30 \mathrm{E}-05$ \\
\hline GO:0016020 & membrane & $1.70 \mathrm{E}-04$ \\
\hline GO:0034361 & very-low-density lipoprotein particle & $3.60 \mathrm{E}-04$ \\
\hline GO:0005840 & ribosome & $8.30 \mathrm{E}-04$ \\
\hline
\end{tabular}




\begin{tabular}{|c|c|c|}
\hline GO:0022627 & cytosolic small ribosomal subunit & $9.90 \mathrm{E}-04$ \\
\hline GO:0042627 & chylomicron & $3.30 \mathrm{E}-03$ \\
\hline GO:0072562 & blood microparticle & $9.70 \mathrm{E}-03$ \\
\hline GO:0034363 & intermediate-density lipoprotein particle & $3.30 \mathrm{E}-02$ \\
\hline GO:0005730 & nucleolus & $3.80 \mathrm{E}-02$ \\
\hline GO:0008180 & COP9 signalosome & $4.60 \mathrm{E}-02$ \\
\hline GO:0005737 & cytoplasm & 4.70E-02 \\
\hline \multicolumn{3}{|c|}{ Molecular Function } \\
\hline GO:0003735 & structural constituent of ribosome & $5.20 \mathrm{E}-10$ \\
\hline GO:0003723 & poly(A) RNA binding & $2.90 \mathrm{E}-09$ \\
\hline GO:0017127 & cholesterol transporter activity & $3.30 \mathrm{E}-04$ \\
\hline GO:0019843 & rRNA binding & $5.20 \mathrm{E}-04$ \\
\hline GO:0060228 & phosphatidylcholine-sterol O-acyltransferase activator activity & $1.40 \mathrm{E}-03$ \\
\hline GO:0003729 & mRNA binding & $6.90 \mathrm{E}-03$ \\
\hline GO:0005543 & phospholipid binding & $1.70 \mathrm{E}-02$ \\
\hline GO:0003743 & translation initiation factor activity & $2.10 \mathrm{E}-02$ \\
\hline GO:0003723 & RNA binding & $3.50 \mathrm{E}-02$ \\
\hline GO:0008035 & high-density lipoprotein particle binding & $3.50 \mathrm{E}-02$ \\
\hline GO:0070653 & high-density lipoprotein particle receptor binding & $3.50 \mathrm{E}-02$ \\
\hline GO:0015485 & cholesterol binding & 4.60E-02 \\
\hline
\end{tabular}

4 